\title{
Dendroarchaeology of shipwrecks and ships in the eastern Mediterranean
}

\author{
Nili Liphschitz* \\ The Botanical Laboratory, Institute of Archaeology, Tel Aviv University, Israel
}

\begin{abstract}
Dendroarchaeology of sunken shipwrecks is at its infancy mainly because of lack of standardized sampling procedures and preservation methods. Early on, samples from shipwrecks were very few and did not represent the variety of tree species of which the vessel was constructed. Moreover, wood samples taken from shipwrecks were either dried or kept in distilled water, which resulted in total decomposition of the wood structure. However, in the last fifteen years proper sampling and preservation of the wood in seawater until its analysis in the laboratory have been developed in Israel. This has enabled species level identification of the wooden parts of the excavated shipwrecks and ships. Results of dendroarchaeology of shipwrecks and ships from the eastern Mediterranean, both from Israel and Turkey, and location of their possible construction sites are presented.
\end{abstract}

Keywords: Aegean coast, AMS radiocarbon dating, dendroarchaeology, Mediterranean, Turkey.

\section{Introduction}

DURING the last five decades comprehensive dendroarchaeological studies have been carried out in Israel on terrestrial archaeological sites belonging to both Pleistocene and Holocene time periods. These sites are distributed throughout the country from the Golan Heights and Mount Hermon to the north to Yotvata and South Sinai to the south. This has enabled reconstruction of arboreal climax vegetation prior to human interference. The macroclimate of the area has remained more or less steady during the Holocene ${ }^{1}$.

Dendroarchaeology deals with species level identification of archaeological wood remains and also processes involved in procuring suitable wood, the source area of wood and dating the time of manufacture of the wooden vessels. Archaeological records have revealed that wood for constructing ships was transported from long distances. There are references to transport of wood from the Indus Valley in South Asia to Mesopotamia for boat building. And similar evidence of long-distance transport of wood is also found in this study of shipwreck dendroarchaeology from the eastern Mediterranean region.

*e-mail: nilili@post.tau.ac.il
The wood samples originating from terrestrial sites, charred or uncharred remains of wood are treated in the laboratory depending on their state of preservation. They are sectioned in a microtome in three directions: cross, tangential longitudinal and radial longitudinal sections. The species level identification is based on the microscopic examination of three-dimensional sections of the wood sample and by comparing them with the reference collection prepared from systematically identified living trees and shrubs and with anatomical atlases available for different geographical regions.

Dendroarchaeological analysis of wood samples from shipwrecks is at its infancy in Israel, mainly because of the lack of standardized sampling procedures and preservation methods. Early on there was little or no attention given to collecting samples from shipwrecks for dendroarchaeological analysis. The majority of samples did not generally belong to the tree from which the vessel was constructed. On the other hand, until recently, wood samples from shipwrecks were either dried or kept in distilled water, that caused complete decomposition of the wood structure. However, in the last fifteen years, proper sampling and preservation of wood from seawater till their analysis in the laboratory have been developed in Israel. Prospects for identification of wood from which the vessels were constructed are now more. In this article results of dendroarchaeological analysis of shipwrecks and ships from eastern Mediterranean region, including Israel and Turkey, are presented by taking into consideration: (i) dendroarchaeology of terrestrial sites and sunken shipwrecks and ships and their differences; (ii) the status of dendroarchaeology of wood samples from shipwrecks; (iii) the assumptions regarding the construction site of the ship, including the provenance studies of wood; and (iv) the contribution of dendroarchaeology for reconstruction and repair of old damaged ships.

\section{Dendroarchaeology of terrestrial sites and shipwrecks and ships}

Dendroarchaeology of terrestrial sites differs from those of sunken ships. The location of the terrestrial archaeological site is well-known, the period to which its layers date is based on the stratigraphy. Objects revealed during the excavation can point to the route it has travelled. The 
local macroclimate prevailing in the area together with the local vegetation contributes to obtaining information on the conditions of the local inhabitants. Regarding shipwrecks, we know only the location where it sank and was found. However, we do not know where it was constructed, which timber was used, where from did the builders obtain the timber and its date of construction. The way to answer these questions is to analyse the timber from which the ship was built up to the species level. Assemblage of all tree species of which the ship was built points to their growth habitat and hence from where they were taken. The AMS radiocarbon dating of treenails made of thin twigs gives the exact date of construction.

\section{Material and methods}

The dendroarchaeological analysis of the timber from each shipwreck aims at precise species level identification of the archaeological wood remains. Wood samples of approximately $0.5-1$ cubic $\mathrm{cm}$ were taken from various timbers of each hull for microscopic examination. Wood samples from shipwrecks are best preserved when kept in seawater until their examination in the laboratory. Unfortunately, some samples that were taken many years ago were preserved either dry or in distilled water, resulting in the deformation of the wood structure. Not all such samples could be identified to the species level. In such cases, dry samples were re-hydrated in tap water to soften them before sectioning. Samples from shipwrecks conserved with polyethylene glycol (PEG) retained their three-dimensional anatomical cellular structure for species-level identification. Following are some of the prerequisites for a successful dendrochronological analysis of the wood samples from sunken ships:

(1) Identification of trees up to the species level.

(2) Proper sampling and storing of wood samples in seawater until the laboratory examination.

(3) Wood samples, representing all parts of the ship, will be useful to locate the region of origin of the trees from which the vessel was built, as well as identify the place of construction.

(4) Botanists should make the identification of the tree species, only when they are familiar with the vegetation of the geographical region where the ship was found. This will avoid mistakes as were made by the USA laboratory people, who identified timbers of Hellenistic, Roman and Byzantine ships as originating from native American tree species.

(5) Care should be taken while collecting samples for AMS radiocarbon dating, young twigs of 2-3 years and nails or pegs made of such twigs gives a good and reliable dating of the ship.

(6) Efforts should be made to develop a reference collection of various tree species for Israel as well as attempts for simultaneous dendrochronological dating of the wood samples.

\section{Shipwrecks found along the Mediterranean coast of Israel}

Ten shipwrecks excavated off the Mediterranean coast of Israel representing several periods have been investigated: the Classical period ship Ma'agan Mikhael (late 5th century BCE); the Medieval period ships: Dor 2001/1 (5th century CE), Dor 2006 (5th-6th centuries CE), Tantura F (8th century CE); Tantura E (7th-9th centuries $\mathrm{CE}$ ); and the Late Ottoman period (Post Medieval, 17th19th centuries CE) ships: Dor C, Dor 2002/2, DW2, Akko 1 and Akko 2 (all five ships date to the 17th-19th centuries $\mathrm{CE})$.

\section{Ma'agan Mikhael}

This small cargo vessel was about $13.5 \mathrm{~m}$ long. The hull was made mainly of Pinus brutia (81.5\%) and several hard woods ${ }^{2-4}$.

\section{Dor $2001 / 1$}

The total length preserved of the hull is $11.5 \mathrm{~m}$. The timber of the keel parts, false keel, planking, ceiling, frames, chine strake, central stringers, planks, wale, mast step sister and end post are of Pinus brutia and Cupressus sempervirens, of several hardwoods and also of Ziziphus spina christi and Tamarix (X5) which are native to Israel that were used for repairs made in the ship on its arrival at Dor ${ }^{3,4}$. This is the earliest Israeli shipwreck which used Cupressus sempervirens as construction timber for the hull.

\section{Dor 2006}

The remains of the wreck were spread along $11 \mathrm{~m}$. The hull timbers including frames, planks, limber boards, ceiling and tenon were made of Pinus brutia, Pinus nigra, Cupressus sempervirens and several hardwoods ${ }^{4}$. This is the next Israeli shipwreck which used Cupressus sempervirens as construction timber for the hull.

\section{Tantura F}

The remains of the wreck were spread over a length of $12 \mathrm{~m}$. The hull was constructed (except for a piece from the keel) of two tree species: Pinus brutia (55\%) and Tamarix smyrnensis $(45 \%)^{3,4}$. Tantura E: The measured length of the wreck was $\sim 7.2 \mathrm{~m}$. The keel, keelson, end post, frames, strakes, stringers, ceiling planking and stanchion were made of Pinus brutia, Cupressus sempervirens and several hardwoods ${ }^{3,4}$. This is the latest Israeli shipwreck which used Cupressus sempervirens as construction timber for the hull. 


\section{Dor $C$}

The wreck is $16 \mathrm{~m}$ long. All ceiling planking, frames, wale, stem, mast and mast step and stanchion were made of Pinus brutia which constituted $85 \%$ of the hull timbers examined ${ }^{4}$.

\section{$D W 2$}

The estimated length of the wreck is $15.5 \mathrm{~m}$. Most of the timbers of the keel, frames, planking and floor timbers (altogether 96\%) were made of Pinus brutia ${ }^{3,4}$. Dor 2002/2: Most of the timber of the planks, frames and treenails (altogether 81\%) was made of Pinus brutia. Other species used were hardwoods ${ }^{3,4}$.

\section{Akko 1}

The shipwreck is $23 \mathrm{~m}$ long. The hull timbers including the keel, false keel, frames, stem, false stem, planks, ceiling planking and apron, were mainly made of Quercus petraea/Quercus pubescens $(61 \%)$ and the remainder of Quercus cerris and Pinus brutia ${ }^{4}$.

\section{Akko 2}

All hull timbers examined, including planks and a keel, were made of Pinus brutia ${ }^{4}$.

\section{The Athlit Ram Galley}

It was discovered at Athlit, $200 \mathrm{~m}$ off-shore and $3 \mathrm{~m}$ deep and has been dated to first half of the 2nd century $\mathrm{BCE}$. The intact bronze ram (Figures 1 and 2) preserved a portion of the wooden hull of the galley from which it

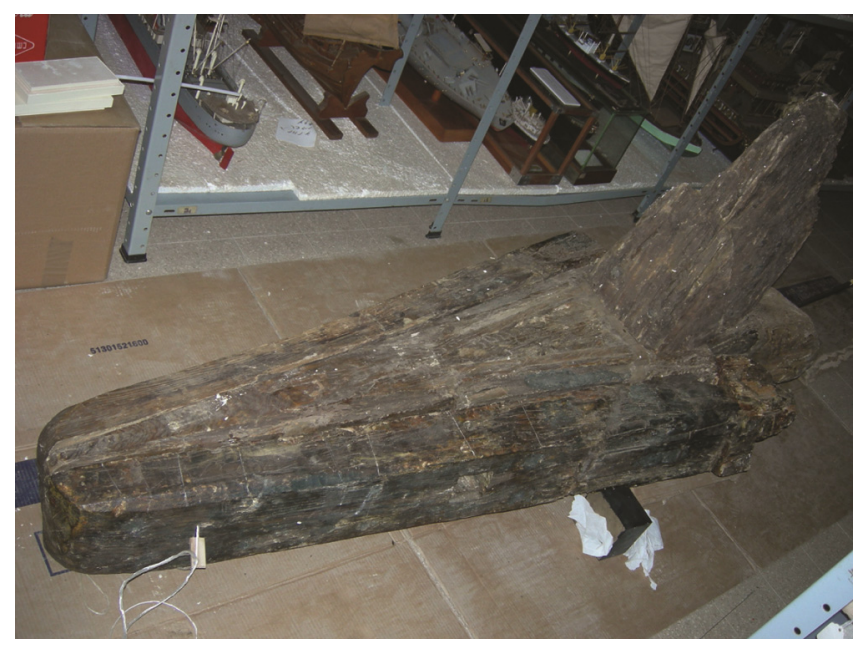

Figure 1. Athlit Ram, displayed at National Maritime Museum in Haifa. CURRENT SCIENCE, VOL. 117, NO. 10, 25 NOVEMBER 2019 became detached in antiquity. The ram is on display in the National Maritime Museum in Haifa and the conserved wooden fragments are located in the museum storeroom. Only 16 wooden parts survived of the hull. They were identified only at the genus level in the United States. The recent reidentification of the wood reveals that the ramming timber and stem were made of Cedrus libani, wales and hull planking of Pinus nigra, nosing timber and chock of Ulmus campestris, and treenails and tenons of Quercus coccifera. All four tree species are native to a wide region, stretching from the south-central Mediterranean coast of Turkey to Syria. It seems that the Athlit galley was built on the mainland, perhaps in the region of Antakya on Turkey's southeastern coast ${ }^{5}$.

\section{Shipwrecks along the Mediterranean and Aegean coast of Turkey}

\section{Two vessels date to the Late Bronze Age}

Uluburun (late 14th century BCE) and Cape Gelidonya (late 13th century BCE): The Uluburun was approximately $15 \mathrm{~m}$ long. Planking of the hull and the keel were made of Cedrus libani and pegs and tenons for the mortise-andtenon joints were made of Quercus coccifera ${ }^{3}$. Cape Gelidonya was a small merchantman about $11.5-12.5 \mathrm{~m}$ long. All planks from the wreck were made of Cedrus libani, one plank fragment was made of Pinus brutia, another was of oak, and three other fragments were made of a coniferous wood ${ }^{3}$. Two vessels are from the Classical

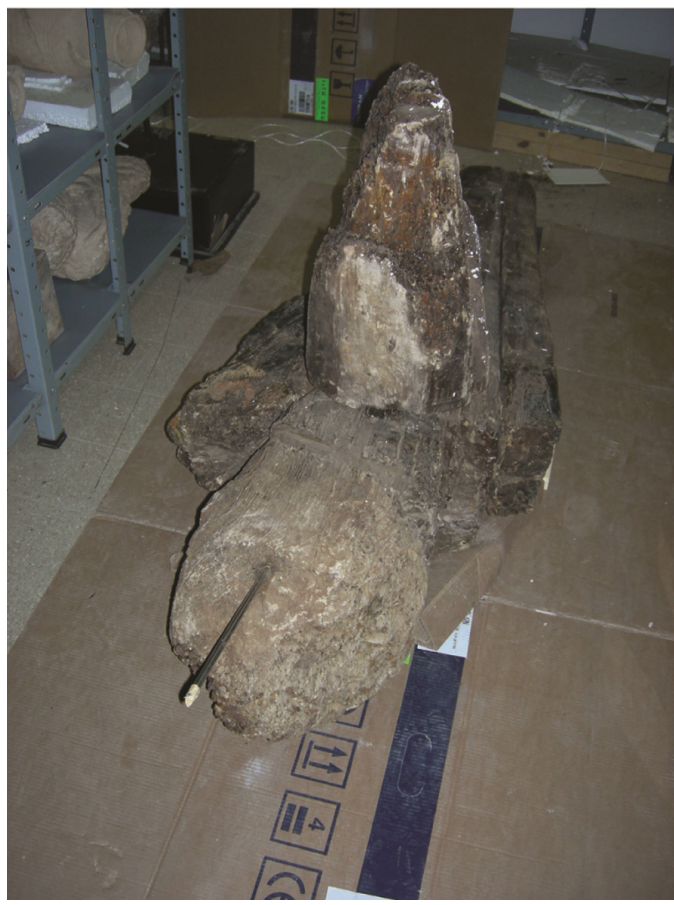

Figure 2. Another view of Athlit Ram, National Maritime Museum in Haifa. 
period: Pabuc Burnu (6th century BCE) and Tektas Burnu (mid-5th century BCE) ships.

\section{Pabuc Burnu}

What has remained were six fragmentary planks, a tenon, a dowel for edge joining the planking and a repair peg. Six planks and a repair peg were made of Pinus nigra, the tenon of Quercus coccifera and the edge dowel was of Nerium oleander ${ }^{3}$.

\section{Tektas Burnu}

A few wood components of the hull have remained. The frames, planking, pegs, and treenails were made of pines: Pinus brutia, Pinus nigra, and Pinus sylvestris ${ }^{3}$.

Thirteen vessels are from the Medieval period: Kizilburun (Late Hellenistic), Yassi Ada (Late Roman; late 4th century CE), Bozburun (late 9th century CE), Yenikapi Shipwrecks, Istanbul: Yenikapi I (second half of 10th century), Yenikapi II (end of 10th century CE), Yenikapi $I V$ (end of 10th to beginning of 11 th century CE), Yenikapi $V$ (end of 10th century CE), Yenikapi XI (MRY5) (7th century CE), Yenikapi XIV (9th to early 10th century $\mathrm{CE}$ ), Yenikapi XXIII (early first half of the 9th century CE) and Yenikapi XXIV (probably early 11th century), Serce Limani (early 11th century CE) and Camalti Burnu (13th century CE) ships.

\section{Kizilburun}

The length of the wreck was $14 \mathrm{~m}$ and was made of pines. The frames, planking, treenail and tenon were made of Pinus brutia and the planking, timbers, keel and garboard were of Pinus nigra ${ }^{6}$. Yassi Ada 4th century CE: The remains of the wreck were approximately $19 \mathrm{~m} \mathrm{long}^{7}$. The planks were made of Cupressus sempervirens and the frames and treenails of Quercus cerris ${ }^{3}$. This ship is the earliest wreck which sank in Turkey in which Cupressus sempervirens was used as hull construction timber.

\section{Bozburun}

The shipwreck was approximately $20 \mathrm{~m}$ long. The keel, stem, seven floor timbers located amidships, hull planking, a futtock, and a treenail were all made of Quercus cerris. Futtocks and floor timbers were made of Pinus brutia $^{3}$.

\section{Yenikapi Shipwrecks, Istanbul}

There are two types of ships: round and long ships.

Yenikapi I: The preserved length is $6.5 \mathrm{~m}$ but its original length was probably about $10 \mathrm{~m}$. The keel, a floor, primary and secondary futtocks, a stringer, strakes, wales, a stem fragment, and all treenails and coaks were of Quercus cerris. Altogether $90 \%$ are of Quercus cerris ${ }^{8}$. Yenikapi V: The preserved length of the wreck is $12 \mathrm{~m}$ and its estimated length is approximately $14.5 \mathrm{~m}$. The keel, floors, futtocks, through-beam, strakes, stem, treenails and most of the coaks were of Quercus cerris ${ }^{8}$.

Yenikapi XI (MRY5): The estimated length of the wreck is $15 \mathrm{~m}$. The stanchion, stringers, chocks and ceiling, as well as a high number of unidentified members were made of Cupressus sempervirens. Strakes, stringers, frames and floors, bulkhead frame, stanchion block, keelson, ceiling was made of Pinus brutia. This is the next shipwreck from Turkey which used Cupressus sempervirens as a timber for the hull construction ${ }^{6}$.

Yenikapi XIV: The preserved length of the ship is $12 \mathrm{~m}$, but its estimated original length could be of $14 \mathrm{~m}$. The great majority of the floors and futtocks were made of Platanus orientalis (84.5\%) The keel and keelson were also made of Platanus orientalis, while all planking was of Pinus nigra ${ }^{8}$.

Yenikapi XXIII: The preserved length of the wreck is 8.9 m long. All hull components examined: keel, keelson, stringers, strakes, wale, stem, frames, floors and edge fasteners were made of Quercus cerris ${ }^{6}$.

Yenikapi XXIV: All components of the wreck: keel, floors, planks, frames, mast step, treenails and edge fasteners, were made of one tree species: Quercus cerris ${ }^{6}$.

Yenikapi II: The preserved length of the ship is $14 \mathrm{~m}$ with an estimated original length of about $30 \mathrm{~m}$. Excluding the treenails and coaks, the ship was built primarily of Platanus orientalis (65\%), Ulmus campestris and Pinus nigra $^{8}$.

Yenikapi IV: The preserved length of the ship is $18 \mathrm{~m}$ and its estimated original length is about $30 \mathrm{~m}$. The great majority of the floors and futtocks were made of Platanus orientalis (Oriental Plane) (85\%). The keel and keelson were also made of Platanus orientalis, while all planking was of Pinus nigra ${ }^{8}$.

Serce Limani: All major components of the hull, including the sternpost, the keel and keelson, frames, wales, planks and ceiling planking were made of Pinus brutia ${ }^{3}$. One vessel is dated to the Post-Medieval period (Ottoman Period), Yassi Ada Ottoman (late 16th century CE) ship. About $58 \%$ of the construction timber was made of Fagus orientalis and above $25 \%$ was made of Quercus cerris ${ }^{9}$.

\section{Origin of the shipwrecks}

All shipwrecks which sank along the Mediterranean coast of Turkey and Israel were built in Turkey. The hulls of 
two ships, dated to the Late Bronze Age: 'Uluburun' and 'Cape Gelidonya', were built with Cedrus libani, suggesting that they were most probably constructed in the region stretching between southeastern Turkey and northwestern Lebanon. All the Yenikapi shipwrecks were built in the area of Istanbul. All other shipwrecks which sank along the Mediterranean coast of Turkey were built most probably in western Turkey. Nine out of ten Israeli shipwrecks were also built most probably in the same area in western Turkey. One shipwreck which sank in Israel, the Tantura $F$, was built in Turkey, either in Antalya in south Turkey or in Izmir in west Turkey.

\section{Ships}

\section{The Kadirga: The Turkish sultan's caique}

The Kadirga - the Turkish Sultan's caique (Figures 3 and 4 ) is on display in the Naval Museum in Istanbul. It is the only original existing galley in the world, which the Ottoman Sultans used for sailing on the Bosphorus,

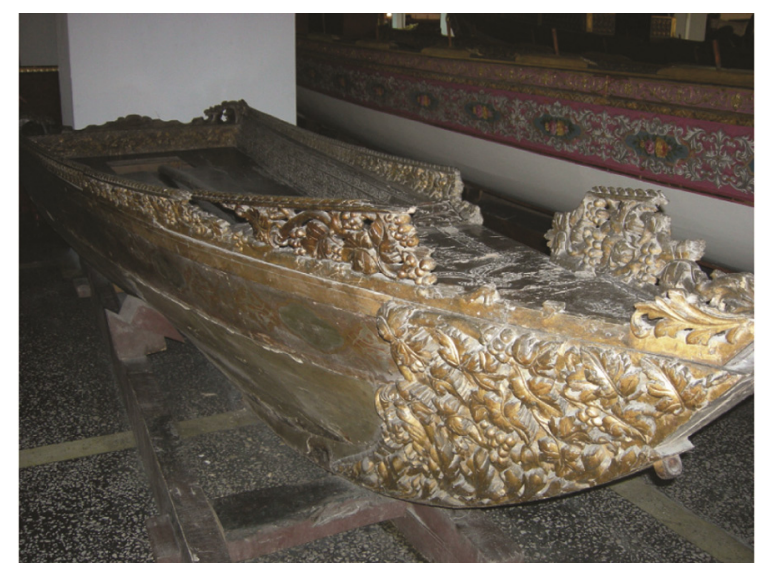

Figure 3. Boat of Sultanate caique, on display in the Naval Museum in Istanbul.

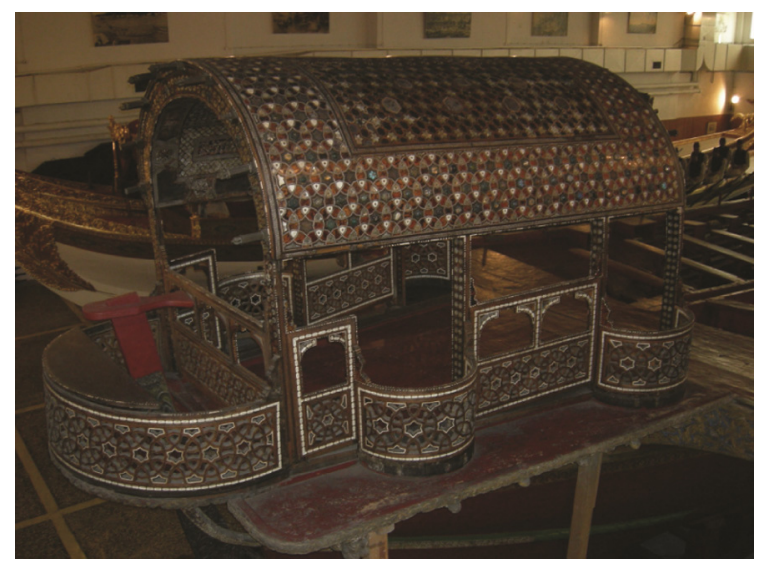

Figure 4. Boat of Sultanate caique, on display in the Naval Museum in Istanbul. mostly for ceremonial occasions. It was built sometime at the end of the 16th century and the middle of the 17th century at the imperial shipyard in the Golden HornIstanbul. It is a $40 \mathrm{~m}$ long oared ship, $5.7 \mathrm{~m}$ wide. The Kiosk (Figure 5) (cabin) is ornamented with geometrical patterns and decorated with mother of pearl, tortoise shell and semi-precious stones and on it there is an inscription with the name Mehmet. The Kadirga was used until the reign of Mahmut II (1808-1839 CE). The ship went over repairs, and part of the timbers was changed in $1885 \mathrm{CE}$ when the ship collapsed and went through a major overhaul.

The kiosk and the kiosk foredeck planking are made of Juglans regia. The original floors and futtocks are made of Quercus cerris. Deck beams are all made of Quercus cerris, and all central gangways are made of Cedrus libani. Most of the painted pieces are made of Pinus brutia, the hull planking is mainly made of Pinus nigra, the wales are of Pinus brutia and the bow deck planking and beams are made of Quercus cerris, Ulmus campestris and Fraxinus excelsior. The benches are mainly made of Cedrus libani. The footrest/supports are mainly made of Pinus nigra and Quercus cerris.

All tree species used to build the Kadirga were native Turkish woody species. The majority grow native till today in the vicinity of Istanbul in Belgrade Forest Nature Reserve which stretches from Iznik to Edirne. It is worth noting that a major part of the ship was made of Quercus cerris while the cabin was made of Juglans regia ${ }^{10}$.

\section{The Imperial (half) boat (Sultanate caique)}

The imperial (half) boat known as the Sultanate caique 230, is on display in the Naval Museum, Istanbul. This boat was the property of the Sultan and served him as a vehicle for short distance transportation. Two parts survived of the boat: the bow section and the stern section. Another part which survived is the Rudder. Several tree

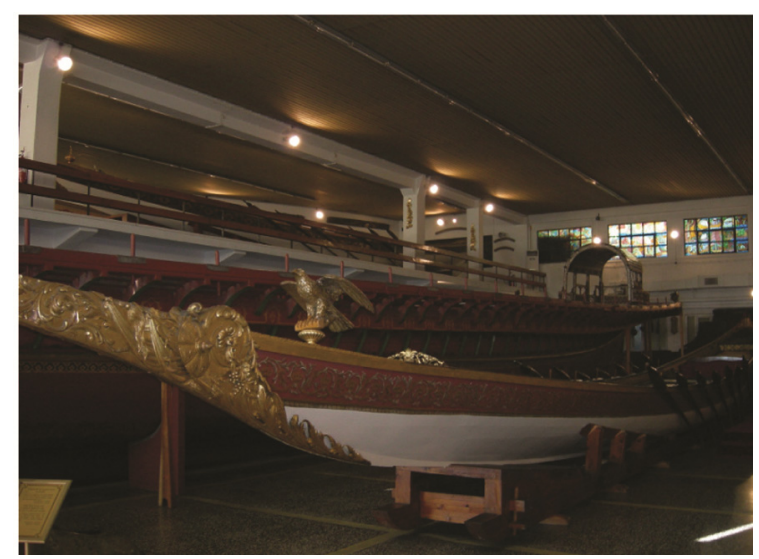

Figure 5. Kiosk of the Kadirga, was in use during 1808-1839 CE. 
species were used to build this boat: Juglans regia for stern deck planking and carved panels, stern post, a spacer, Fagus orientalis for cap rail, wale, deck beam over frames, carved panel over cap rail, aft end wedges, aft carved decoration, keelson, long supporting timber, forward segment, rudder blade and decorations on port and starboard sides, Fraxinus excelsior for port and starboard futtocks, floor, port and starboard frames, bulwarks, Quercus cerris for planks on starboard and port sides, Quercus sp. for tenon, Tilia cordata for one carved decorative beam and one carved uppermost stern decoration, Pinus nigra for 2 stringers on the lower edge of carved panels, 2 planks on portside and 2 planks on starboard side, and Betula pubescens/Betula pendula for a thole on the portside of the ship ${ }^{11}$.

1. Liphschitz, N., Timber in Ancient Israel: Dendroarchaeology and Dendrochronology. Monograph Series 26, Institute of Archaeology, Tel Aviv University, Tel Aviv, 2007.

2. Liphschitz, N., Dendroarchaeological investigations. In The Ma'agan Mikhael Ship - The Recovery of a 2400 Years Old Merchantman: Final Report (eds Tresman, J., Kahanov, Y. and Linder, E.), Israel Exploration Society and Haifa University, Haifa, 2004, pp. 156-163.

3. Liphschitz, N. and Pulak, C., Wood species used in ancient shipbuilding in Turkey: evidence from dendroarchaeological studies. Skyllis, 2007-8, 8(1-2), 73-82.

4. Liphschitz, N., Dendroarchaeological studies of shipwrecks along the Mediterranean coast of Israel. In Environment and Ecology in the Mediterranean Region (ed. Efe, R.), Cambridge Scholars Publishing, Cambridge, 2013, pp. 1-12.

5. Liphschitz, N. and Pulak, C., The Athlit Ram timbers re-examined: tree species identification and possible construction site of the galley. Tropis, 2008, 10.

6. Liphschitz, N., Cupressus sempervirens (Cypress) as hull construction timber of sunken shipwrecks in the East Mediterranean. In Maritime Archaeology: Revelation of the Past through Shipwrecks around the World (ed. Sila Tripati), Delta Book World, New Delhi, 2015, pp. 604-623.

7. Bass, G. F. and Van Doorninck, F. H., A fourth century shipwreck at Yassi Ada. Am. J. Archaeol., 1971, 75, 27-37.

8. Liphschitz, N. and Pulak, C., Shipwrecks of Portus Theodisiacus: type of wood used in some Byzantine Roundships and Longships at Yenikapi, Istanbul. Skyllis, 2009, 9, 164-171.

9. Liphschitz, N., Three Yassi Ada wrecks: a comparative dendroarchaeological investigation. Skyllis, 2014, 14, 203-207.

10. Liphschitz, N., The Kadirga galley in Istanbul-the Turkish Sultan's Caique: a dendrohistorical research. In Environment and Ecology in the Mediterranean Region II (eds Efe, R. and Ozturk, M.), Cambridge Scholars Publishing, Cambridge, 2014, pp. 39-48.

11. Liphschitz, N., The Sultanate Caique. Mimeographed Report 473, Institute of Archaeology, Tel Aviv University, 2007.

ACKNOWLEDGEMENT. I thank Dr Cemal Pulak of Texas A\&M University for his cooperation, most valuable suggestions and comments.

doi: $10.18520 / \mathrm{cs} / \mathrm{v} 117 / \mathrm{i} 10 / 1617-1622$ 